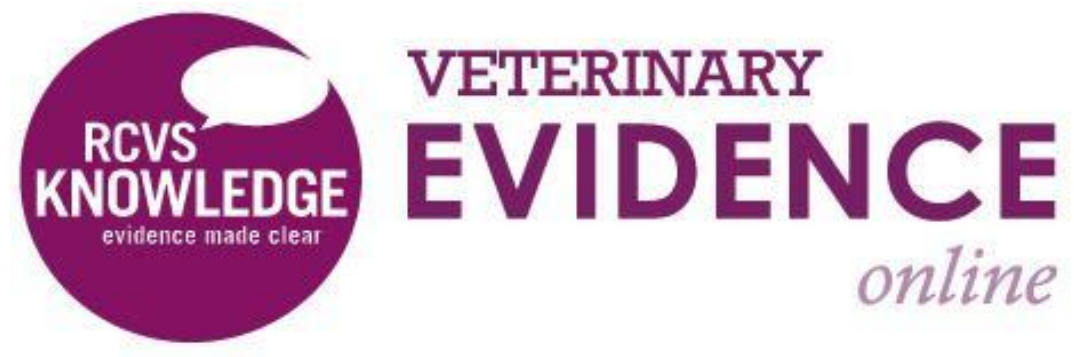

\title{
In Dogs That Have Had Intussusception Does Enteroplication Prevent Recurrence?
}

\section{A Knowledge Summary by}

Foteini Kormpou DVM, MRCVS ${ }^{1^{*}}$

Sophie Adamantos BVSc, CertVA, DACVECC, DipECVECC, MRCVS, FHEA ${ }^{1}$

\footnotetext{
${ }^{1}$ University of Bristol, Senate House, Tyndall Ave, Bristol BS8 1TH

*Corresponding Author (FoteiniKormpou@hotmail.com)
}

ISSN: 2396-9776

Published: 09 Jan 2018

in: Vol 3, Issue 1

DOI: http://dx.doi.org/10.18849/ve.v3i1.129

Reviewed by: Bruce Smith (BVSc MS FANZCVS DACVS) and Gillian Monsell (MA, VetMB, PhD, MRCVS) 


\section{KNOWLEDGE SUMMARY}

\section{Clinical bottom line}

The number of published primary papers on enteroplication as a preventative surgical procedure for recurrent intussusception is currently low with a relatively small number of cases reported in the studies. The studies did not demonstrate a statistical difference in the recurrence rate with or without the procedure although there was a consistent trend for a reduction in the recurrence rate with enteroplication.

Enteroplication has also been associated with severe complications, thus surgeons must weigh the risk of recurrent intussusception against the risk of complications with enteroplication. More definitive conclusions cannot be made until higher quality evidence is available on the topic.

\section{Question}

In Dogs That Have Had Intussusception Does Enteroplication Prevent Recurrence?

\section{Clinical Scenario}

You are presented with an eight-month old male entire Golden Retriever that has been diagnosed with intussusception based on the history, physical examination and radiographic findings. You wonder whether doing an enteroplication, as part of this dog's surgical treatment, is going to reduce the probability of recurrent intussusception.

\section{Summary of the evidence}

\begin{tabular}{|c|l|}
\hline \multicolumn{2}{|l|}{ Levitt (1992) } \\
\hline Population: & $\begin{array}{l}\text { Thirty-six cases (27 dogs and 9 cats) with confirmed diagnosis of } \\
\text { intussusception through clinical history, physical examination, plain } \\
\text { abdominal radiography and contrast radiography, during a 7-year } \\
\text { period. }\end{array}$ \\
\hline Sample size: & Twenty-seven dogs and nine cats. \\
\hline Intervention details: & $\begin{array}{l}\text { (i) Simple reduction was performed in 10 dogs, } 4 \text { of which also } \\
\text { underwent intestinal plication. } \\
\text { (ii) Intestinal resection and anastomosis were deemed necessary in } \\
14 \text { dogs, 2 of which also underwent intestinal plication. }\end{array}$ \\
\hline Study design: & $\begin{array}{l}\text { No surgery was performed in 3 cases and these dogs were } \\
\text { euthanised at the request of their owners. }\end{array}$ \\
\hline Outcome studied: & $\begin{array}{l}\text { Retrospective single-centre case series. } \\
\text { Identification of a common predisposing cause, correlation between } \\
\text { the duration of clinical signs or location of lesion and the presence of }\end{array}$ \\
\hline &
\end{tabular}




\begin{tabular}{|c|c|}
\hline & $\begin{array}{l}\text { adhesions, and simple associations of the recurrence rate versus the } \\
\text { surgical technique utilised and the bowel segment involved. }\end{array}$ \\
\hline $\begin{array}{l}\text { Main findings: } \\
\text { (relevant to PICO question): }\end{array}$ & $\begin{array}{l}\text { (i) In 3/10 dogs that had simple reductions an intussusception } \\
\text { recurred within } 24-120 \text { hours after the initial surgery, } 1 \text { of which had } \\
\text { also undergone jejunal plication. } \\
\text { (ii) In } 2 / 14 \text { dogs that had intestinal resection/anastomosis alone an } \\
\text { intussusception recurred within } 24-120 \text { hours after the initial } \\
\text { surgery. } \\
\text { - No common predisposing cause could be } \\
\text { established. } \\
\text { - Intussusception recurrence rate is not related either } \\
\text { to the surgical technique utilised or to the bowel } \\
\text { segment involved. } \\
\text { - No correlation could be established between the } \\
\text { duration of the clinical signs or the location of the } \\
\text { lesion and the presence of adhesions. }\end{array}$ \\
\hline Limitations: & $\begin{array}{l}\text { - The study is retrospective, with a small number of cases. } \\
\text { - The study was performed on data from a single referral } \\
\text { teaching hospital (multiple hospitals would be preferable in } \\
\text { order to obtain more generalisable results; also different } \\
\text { hospitals might have different processes/protocols). } \\
\text { - The study is } 25 \text { years old. } \\
\text { - The efficacy of enteroplication, as a prophylactic measure, } \\
\text { could not be adequately demonstrated due to small number } \\
\text { of cases in which plication was performed. } \\
\text { - Long-term follow-up is not available for all the cases. } \\
\text { - The cases cover a seven-year period. } \\
\text { The dog that had the recurrence of the intussusception post } \\
\text { plication (just proximal to site of plication) had undergone a } \\
\text { jejunal plication and not a complete plication of the jejunum } \\
\text { and ileum, which is the recommended technique (Wolfe, } \\
\text { 1977). This is due to the propensity for intussusceptions to } \\
\text { recur at anatomic sites different from the primary lesion. } \\
\text { - It is not clear whether any of the other } 5 \text { dogs that } \\
\text { underwent plication had their entire small intestine plicated } \\
\text { or just a segment of it. }\end{array}$ \\
\hline
\end{tabular}

\begin{tabular}{|r|l|}
\hline \multicolumn{2}{|l|}{ Oakes (1994) } \\
\hline Population: & $\begin{array}{l}\text { Thirty-one dogs that had undergone surgery for correction of } \\
\text { intussusceptions and had been followed up for at least } 21 \text { days after } \\
\text { surgery, during a 14-year period. }\end{array}$ \\
\hline Sample size: & Thirty-one dogs. \\
\hline Intervention details: & $\begin{array}{l}\text { (i) Simple reduction was performed in } 3 \text { dogs. } \\
\text { (ii) Resection and anastomosis was performed in } 26 \text { dogs. } \\
\text { (iii) Simple reduction with serosal patch application was performed } \\
\text { in } 1 \text { dog. } \\
\text { (iv) Details of the surgery were not available for } 1 \text { dog. }\end{array}$ \\
\hline
\end{tabular}




\begin{tabular}{|c|c|}
\hline & $\begin{array}{l}\text { Enteroplication was performed in } 9 \text { dogs. From these, } 5 \text { had their } \\
\text { entire ileum and jejunum plicated, } 3 \text { only had a small segment of } \\
\text { their small intestine plicated and for } 1 \text { dog there were no details of } \\
\text { the enteroplication procedure available. }\end{array}$ \\
\hline Study design: & Retrospective dual-centre case series. \\
\hline Outcome studied: & $\begin{array}{l}\text { Efficacy of enteroplication in preventing recurrence of } \\
\text { intussusception in dogs and determination of its adverse clinical } \\
\text { effects. }\end{array}$ \\
\hline $\begin{array}{r}\text { Main findings: } \\
\text { (relevant to PICO question): }\end{array}$ & $\begin{array}{l}\text { - A total of } 6 / 22 \text { ( } 28 \% \text { ) dogs that did not undergo } \\
\text { enteroplication had a recurrence } 1-9 \text { days post } \\
\text { operatively: } \\
\text { (i) One dog that had undergone simple reduction. } \\
\text { (ii) Five dogs that had undergone resection and } \\
\text { anastomosis; In one case the intussusception was } \\
\text { caused by the continuous presence of a linear } \\
\text { foreign body. } \\
\text { - None of the dogs that underwent enteroplication } \\
\text { had a recurrence. } \\
\text { Complications after surgery included diarrhoea in } \\
6 / 9(67 \%) \text { dogs with and in } 10 / 22 \text { ( } 45 \% \text { ) dogs } \\
\text { without enteroplication and anastomotic leakage } \\
\text { requiring second surgery in } 2 / 9 \text { ( } 22 \% \text { cases with and } \\
\text { in } 2 / 22(9 \%) \text { cases without enteroplication. } \\
\text { In } 13 / 16 \text { ( } 81 \% \text { ) cases without and in } 10 / 13 \text { ( } 77 \%) \\
\text { cases with enteroplication (plication having been } \\
\text { performed at initial surgery or after recurrence) } \\
\text { became clinically normal without any } \\
\text { gastrointestinal abnormalities } 3 \text { days }-3 \text { months } \\
\text { after surgery, according to their owners. One dog } \\
\text { that had enteroplication developed canine } \\
\text { distemper and was euthanised. }\end{array}$ \\
\hline Limitations: & $\begin{array}{l}\text { - The study is retrospective, with a small number of cases. } \\
\text { - The study is } 23 \text { years old; new scientific data might have } \\
\text { been published since then on this subject and different } \\
\text { protocols might be being used. } \\
\text { - The efficacy of enteroplication as a prophylactic measure } \\
\text { could not be adequately demonstrated due to small number } \\
\text { of cases in which plication was performed. } \\
\text { - It is not clear whether the dogs that underwent } \\
\text { enteroplication had previously undergone simple reduction } \\
\text { or resection and anastomosis. } \\
\text { - Long-term follow-up with regards to post op complications } \\
\text { and survival is not available for all the cases. } \\
\text { - } \quad \text { In three dogs the plication involved only a small segment of } \\
\text { the small intestine and not the entire jejunum and ileum, } \\
\text { which is the recommended technique (Wolfe, 1977). } \\
\text { Follow-up information was sometimes collected from the }\end{array}$ \\
\hline
\end{tabular}




\begin{tabular}{|l|l|}
\hline & $\begin{array}{l}\text { owners and not vet reports. } \\
\text { - }\end{array}$ \\
& $\begin{array}{l}\text { It is not clear whether the dog that developed distemper } \\
\text { post operatively has had investigations for that prior to } \\
\text { surgery, since this could have potentially been a } \\
\text { predisposing factor all along. }\end{array}$ \\
\hline
\end{tabular}

\begin{tabular}{|c|c|}
\hline \multicolumn{2}{|l|}{ Applewhite (2001) } \\
\hline Population: & $\begin{array}{l}\text { Thirty-five dogs with intestinal intussusception diagnosed by means } \\
\text { of ultrasonography or exploratory celiotomy. }\end{array}$ \\
\hline Sample size: & Thirty-five dogs. \\
\hline Intervention details: & $\begin{array}{l}\text { - Intussusception was spontaneously reduced in } 1 \text { dog. } \\
\text { - Simple reduction was performed in } 7 \text { dogs. } \\
\text { - Resection and anastomosis were deemed necessary in } 27 \\
\text { dogs. } \\
\text { - Intestinal plication was performed in } 16 \text { dogs, } 10 \text { of which had } \\
\text { undergone resection and anastomosis, } 5 \text { had undergone } \\
\text { manual reduction and } 1 \text { had spontaneous reduction. }\end{array}$ \\
\hline Study design: & Retrospective dual-centre case series. \\
\hline Outcome studied: & $\begin{array}{l}\text { Comparison of complications and recurrence rates in dogs treated } \\
\text { for intestinal intussusception that underwent enteroplication (of } \\
\text { their entire jejunum and ileum) to rates in dogs treated for } \\
\text { intussusception that did not undergo enteroplication. }\end{array}$ \\
\hline $\begin{array}{l}\text { Main findings: } \\
\text { (relevant to PICO question): }\end{array}$ & $\begin{array}{l}\text { - None of the dogs that underwent enteroplication } \\
\text { had a recurrence, whereas } 1 \text { of the } 19 \text { dogs that did } \\
\text { not undergo enteroplication had a recurrence } 48 \\
\text { hours post operatively. } \\
\text { - Three dogs developed complications associated with } \\
\text { enteroplication. In } 2 \text { dogs, intestinal obstruction } \\
\text { developed because of material that was unable to } \\
\text { pass through. In the third dog, a segment of small } \\
\text { intestine became strangulated between } \\
\text { enteroplication sutures in the jejunum. } \\
\text { - Statistical analysis revealed no significant difference } \\
\text { in the likelihood of recurrence of intussusception } \\
\text { between the dogs that underwent enteroplications } \\
\text { at their first surgery and dogs that did not. } \\
\text { - The likelihood of undergoing a second surgery either } \\
\text { due to a complication or due to recurrence was not } \\
\text { significantly different between the two groups. }\end{array}$ \\
\hline Limitations: & $\begin{array}{l}\text { - The study is retrospective, with a small number of cases. } \\
\text { - The study is } 16 \text { years old; new scientific data might have } \\
\text { been published since then on this subject and different } \\
\text { protocols might be being used. } \\
\text { - The cases cover an eleven-year period. } \\
\text { - Follow-up information was sometimes collected from the }\end{array}$ \\
\hline
\end{tabular}




\begin{tabular}{|c|c|}
\hline \multicolumn{2}{|l|}{ Wolfe (1977) } \\
\hline Population: & $\begin{array}{l}\text { Two young dogs with subsequent recurrent intestinal } \\
\text { intussusception within } 3 \text { days of initial surgical reduction. }\end{array}$ \\
\hline Sample size: & Two dogs. \\
\hline Intervention details: & $\begin{array}{l}\text { - Simple reduction was performed in both dogs. One dog } \\
\text { developed } 2 \text { subsequent intussusceptions on the } 3^{\text {rd }} \text { and on } \\
\text { the } 4^{\text {th }} \text { postoperative day. The first one was managed with } \\
\text { simple reduction and the second one with resection and } \\
\text { anastomosis and enteroplication from the duodenocolic } \\
\text { ligament to the descending colon. } \\
\text { - One dog developed } 1 \text { recurrent intussusception on the } 2^{\text {nd }} \\
\text { postoperative day. This was managed with simple reduction } \\
\text { and enteroplication from the duodenocolic ligament to the } \\
\text { descending colon. }\end{array}$ \\
\hline Study design: & Case reports \\
\hline Outcome studied: & Not applicable. \\
\hline $\begin{array}{l}\text { Main findings: } \\
\text { (relevant to PICO question): }\end{array}$ & $\begin{array}{l}\text { - Subsequent recurrence of intestinal intussusception was } \\
\text { prevented with intestinal plication in both cases. } \\
\text { - No complications were noted following enteroplication in } \\
\text { these cases. }\end{array}$ \\
\hline Limitations: & $\begin{array}{l}\text { - Very small number of cases, thus very difficult to draw } \\
\text { conclusions safely. } \\
\text { - } \quad \text { The study is } 25 \text { years old. } \\
\text { - } \quad \text { Data from callow-up is not available for the cases. } \\
\text { drawn from it, clearly do not have the weight of findings that } \\
\text { other types of research studies have. }\end{array}$ \\
\hline
\end{tabular}

\section{Appraisal, application and reflection}

Recurrence of intussusception following surgical correction is not uncommon in dogs; the recurrence rate was reported to be as high as $22 \%$ in one study (Levitt, 1992). It usually occurs within 20 days of surgery and is most commonly reported to be proximal to the initial intussusception site. When a predisposing factor for intussusception has not been identified techniques for prevention of recurrence should be considered (Wolfe, 1977). Enteroplication is a surgical technique that has been used within the studies as a way to prevent recurrence of intussusception. However, not many studies have been carried out to determine its efficacy and the possible complications that it might involve. All relevant studies identified that discuss the efficacy of enteroplication as a prophylactic measure for recurrent intussusception are old retrospective case series and case reports, that only involve a small number of cases. Retrospective case series and case reports sit low on the hierarchy of evidence, so, it would be difficult to draw definitive conclusions from the available literature.

It appears, though, that enteroplication reduced the probability of recurrent intussusception in all the studies, but statistical analysis did not reveal any significant difference in the likelihood of recurrence of intussusception between dogs that underwent enteroplication at the first surgery and dogs that did not. Further to this, it appears that enteroplication can result into severe complications, including intestinal 
obstruction with vegetative material and strangulation of enteroplicated loops between enteroplication sutures. All three retrospective case series that were identified recommend that the plication, when performed, should include the entire small intestine from the distal duodenum to the distal ileum (Applewhite, 2001; Levitt, 1992; Oakes, 1994). The only case that developed subsequent recurrent intussusception following enteroplication in one study had undergone a jejunal plication alone (Levitt, 1992).

Due to the retrospective nature of these studies it is impossible to definitively state that plication reduces recurrence rate since there could be other factors, which have not yet been identified, affecting that as well. In order to fully evaluate the role of enteroplication in preventing recurrent intussusceptions a prospective, multi-institutional, randomised clinical study using a standardised enteroplication technique is needed. Therefore, until higher quality research is available, veterinary surgeons must weigh the risk of recurrent intussusception against the risk of complications with enteroplication.

\section{Methodology Section}

\begin{tabular}{|c|c|}
\hline \multicolumn{2}{|l|}{ Search Strategy } \\
\hline $\begin{array}{r}\text { Databases searched and dates } \\
\text { covered: }\end{array}$ & $\begin{array}{l}\text { CAB Abstracts via the Ovid platform covering from } 1973 \text { to } 2017 \\
\text { Week 19. Medline via the Ovid platform covering from } 1946 \text { to } 2017 \text {. } \\
\text { The reference list for the studies that were identified has also been } \\
\text { searched. }\end{array}$ \\
\hline Search terms: & $\begin{array}{l}\text { (dog OR dogs OR canine OR canid*) AND (intussusception) AND } \\
\text { (enteroplication) }\end{array}$ \\
\hline Dates searches performed: & May 8th 2017 \\
\hline
\end{tabular}

\begin{tabular}{|c|c|}
\hline Exclusion: & $\begin{array}{l}\text { Comment letters, single case reports and articles which were not } \\
\text { relevant to the PICO question. }\end{array}$ \\
\hline Inclusion: & $\begin{array}{l}\text { Articles available in English which were relevant to the PICO. Articles } \\
\text { had to involve more than one animal. The reference checklist for } \\
\text { each study that was identified was also searched. }\end{array}$ \\
\hline
\end{tabular}

Please add rows as necessary

\begin{tabular}{|l|c|c|c|c|c|c|}
\hline \multicolumn{2}{|c|}{ Search Outcome } \\
\hline Database & $\begin{array}{c}\text { Number } \\
\text { of } \\
\text { results }\end{array}$ & $\begin{array}{c}\text { Excluded }- \\
\text { Comment } \\
\text { letter }\end{array}$ & $\begin{array}{c}\text { Excluded }- \\
\text { single case } \\
\text { report }\end{array}$ & $\begin{array}{c}\text { Excluded - } \\
\text { irrelevant to } \\
\text { PICO }\end{array}$ & $\begin{array}{c}\text { Excluded - not } \\
\text { accessible }\end{array}$ & $\begin{array}{c}\text { Total } \\
\text { relevant } \\
\text { papers }\end{array}$ \\
\hline CAB Abs & 8 & 1 & 2 & 3 & 0 & 2 \\
\hline Medline & 8 & 1 & 2 & 3 & 0 & 2 \\
\hline
\end{tabular}




\begin{tabular}{|l|c|c|c|c|c|}
\hline $\begin{array}{l}\text { Reference } \\
\text { list checking }\end{array}$ & 22 & 0 & 3 & 17 & 0 \\
\hline \\
Total relevant papers when duplicates removed
\end{tabular}

\section{CONFLICT OF INTEREST}

The authors declare no conflict of interest.

\section{REFERENCES}

1. Applewhite, A.A. et al. (2001) Complications of enteroplication for the prevention of intussusception recurrence in dogs: 35 cases (1989-1999). Journal of the American Veterinary Medical Association, 219 (10) pp.1415-8. DOI: http://dx.doi.org/10.2460/javma.2001.219.1415

2. Levitt, L. et al. (1992) Intussusception in dogs and cats: A review of 36 cases. Canadian Veterinary Journal, 33 (10) pp. 660-664.

3. Oakes, M.G. et al. (1994) Enteroplication for the prevention of intussusception recurrence in dogs: 31 cases (1978-1992). Journal of the American Veterinary Medical Association, 205 (1) pp.72-5.

4. Wolfe, D. A. (1977) Recurrent intestinal intussusceptions in the dog. Journal of the American Veterinary Medical Association, 171(6) pp.553-6. 


\section{Cinam \\ ochese}

\section{Intellectual Property Rights}

Authors of Knowledge Summaries submitted to RCVS Knowledge for publication will retain copyright in their work, and will be required to grant to RCVS Knowledge a non-exclusive license of the rights of copyright in the materials including but not limited to the right to publish, re-publish, transmit, sell, distribute and otherwise use the materials in all languages and all media throughout the world, and to license or permit others to do so.

\section{Disclaimer}

Knowledge Summaries are a peer-reviewed article type which aims to answer a clinical question based on the best available current evidence. It does not override the responsibility

of the practitioner. Informed decisions should be made by considering such factors as individual clinical expertise and judgement along with patient's circumstances and owners' values. Knowledge Summaries are a resource to help inform and any opinions expressed within the Knowledge Summaries are the author's own and do not necessarily reflect the view of the RCVS Knowledge.

Veterinary Evidence and EBVM Network are RCVS Knowledge initiatives. For more information please contact us at editor@veterinaryevidence.org

RCVS Knowledge is the independent charity associated with the Royal College of Veterinary Surgeons (RCVS). Our ambition is to become a global intermediary for evidence based veterinary knowledge by providing access to information

that is of immediate value to practicing veterinary professionals and directly contributes to evidence based clinical decision-making.

www.veterinaryevidence.org

RCVS Knowledge is a registered Charity No. 230886. Registered as a Company limited by guarantee in England and Wales No. 598443.

Registered Office:

Belgravia House

62-64 Horseferry Road

London SW1P 2AF 